\title{
PENGENALAN NILAI-NILAI AKHLAK MULIA MELALUI METODE PEMBIASAAN DI RA AL ROSYID BOJONEGORO
}

\author{
Ulfa, M.Pd.I \\ ulfamasyhur8@gmail.com
}

IAI Sunan Giri Bojonegoro

\begin{abstract}
Education is a lifelong human need, early childhood education aims to provide stimulation and guidance on physical tenderness and growth, so as to improve intellectual abilities and social relations in preparation for further education. Children are parents' hopes, their education must be considered since they are at an early age, because at an early age giving education to them is very influential. Today's many community phenomena cannot be controlled in their moral values, because of lack of good education at an early age, and in providing education at an early age must be a method that is easy for them to understand, then the introduction of moral values should be given since the child early age and with the correct method among the methods is the habitual method. to see this truth the author took research at the RA al Rosyid Bojonegoro school, which became a favorite school in that city
\end{abstract}

KeyWords; Habit, Moral, Values

\section{A. PENDAHULUAN.}

Anak adalah amanah yang diberikan Allah SWT kepada orang tua yang diibaratkan oase di tengah-tengah gurun pasir yang kering dan tandus. la akan memberi kepuasan ketika dahaga, memberi keteduhan ketika panas, dan memberikan kebahagiaan ketika datang nestapa. Pada anaklah tergantung cita dan cinta orang tua. Dengan anaklah orang tua akan mengarungi bahtera kehidupan. Dan doa anaklah yang akan memberi kesejukan dan kebahagiaan di alam akherat. Semua itu akan menjadi sebuah keniscayaan apabila seorang anak mendapat pendidikan yang tepat, sehingga berguna bagi orang tua, lingkungan, masyarakat dan negara.

\footnotetext{
${ }^{1}$ Dosen IAI Sunan Giri Bojonegoro
} 
Menurut ajaran Islam, persiapan mendidik anak dimulai sejak pemilihan jodoh, yaitu pemilihan istri atau suami. Dan pendidikan tidak dapat berawal dari pertengahan jalan. Pendidikan hendaknya bermuara dari kebeningan cinta, dan rasa kasih sayang, melalui tata cara yang dipolakan dengan penuh kehangatan, keamanan, serta berjuang pada pencapaian ridha Allah swt. ${ }^{2}$

Anak usia dini merupakan suatu proses pembinaan tumbuh kembang anak usia lahir hingga enam tahun secara menyeluruh, yang mencakup aspek fisik dan non fisik, dengan memberikan rangsangan bagi perkembangan jasmani dan rohani (moral dan spiritual) motorik, akal pikir, emosional dan sosial yang tepat agar anak dapat tumbuh dan berkembang secara optimal. ${ }^{3}$

Anak usia dini merupakan suatu proses pembinaan tumbuh kembang anak usia lahir hingga enam tahun secara menyeluruh, yang mencakup aspek fisik dan non fisik, dengan memberikan rangsangan bagi perkembangan jasmani dan rohani (moral dan spiritual) motorik, akal pikir, emosional dan sosial yang tepat agar anak dapat tumbuh dan berkembang secara optimal. ${ }^{4}$

Pendidikan merupakan kebutuhan manusia sepanjang hayat,Pendidikan usia dini bertujuan untuk memberikan stimulasi dan bimbingan terhadap kelembutan fisik dan pertumbuhannya, sehingga meningkatkan kemampuan intelektual dan hubungan sosial sebagai persiapan untuk masuk ke jenjang pendidikan selanjutnya. ${ }^{5}$ Sedangkan

${ }^{2}$ Ahmad Tafsir, Pendidikan Agama Dalam Keluarga, (Bandung : Remaja Rosdakarya, 2000), hal. 72.

3 Jamal Ma'mur Asmani, Manajemen Stategis Pendidikan Anak Usia Dini, (Yogyakarta: Diva Press, 2009), hal. 53.

${ }^{4}$ Mursid, Kurikulum Dan Pendidikan Anak Usia Dini (PAUD), (Semarang : AKFI Media, 2010), hal. 48.

5 Jamal Ma'mur Asmani, Manajemen Stategis Pendidikan Anak Usia Dini, (Yogyakarta:Diva Press, 2009), hal. 53 
Pendidikan nilai mencakup kawasan budi pekerti, nilai, norma, dan moral. ${ }^{6}$

Sesuai pendapat Harun Al Rasyid yang dikutip oleh Jamal Ma'mur Asmani, beliau mengungkapkan bahwa pemberian pendidikan pada anak usia dini diakui sebagai periode yang sangat penting dalam membangun sumber daya manusia dan periode ini akan datang hanya sekali serta tidak dapat diulang lagi, sehingga pemberian stimulasi dini, salah satunya adalah pendidikan mutlak diperlukan. ${ }^{7}$ Secara umum Pendidikan anak usia dini bertujuan untuk mengembangkan berbagai potensi anak-anak sejak dini sebagai persiapan untuk hidup dan dapat menyesuaikan diri dengan lingkungannya serta membentuk anak Indonesia yang berkualitas, dimana anak akan tumbuh dan berkembang sesuai dengan tingkat perkembangannya sehingga memiliki kesiapan optimal dalam memasuki pendidikan dasar, serta mengarungi kehidupan di masa dewasanya. ${ }^{8}$

Agar kelak dapat berfungsi sebagai manusia yang sesuai dengan falsafah suatu bangsa. Anak perlu dibimbing agar dapat mengetahui fenomena alam dan dapat melakukan keterampilan-keterampilan yang dibutuhkan untuk hidup di masyarakat kelak. Usia dini merupakan saat yang sangat berharga untuk mengenalkan nilai-nilai nasionalisme, agama, etika, moral dan sosial yang berguna untuk kehidupan selanjutnya. ${ }^{9}$

Dalam Undang- Undang Sistem Pendidikan Nasional (UU SISDIKNAS) No. 20 Tahun 2003 pada BAB 1 pasal 1 ayat 12 disebutkan: "Pendidikan nonformal adalah jalur pendidikan di luar pendidikan formal yang dapat dilaksanakan secara terstruktur dan berjenjang " sedangkan dalam pasal 1 ayat 14 , dijelaskan pengertian pendidikan anak usia dini yang berbunyi:

\footnotetext{
${ }^{6}$ Masnur Muslich, Pendidikan Karakter Menjawab Tantangan Krisis Multidimensional (Jakarta: Bumi Aksara, 2011), hal. 72.

7 Jamal Ma'mur Amani, hal. 42.

8 Mursid, Manajemen Lembaga Pendidikan Anak Usia Dini, (Semarang: Akfi Media, 2010), hal.4

9 Slamet Suyanto, Dasar-Dasar Pendidikan Anak Usia Dini, (Yogyakarta: Hikayat Publishing, 2005), hal. 4.
} 
“Pendidikan anak usia dini adalah suatu upaya pembinaan yang ditujukan kepada anak sejak lahir sampai usia 6 tahun yang dilakukan melalui pemberian rangsangan pendidikan untuk membantu pertumbuhan dan perkembangan jasmani dan rohani agar anak memiliki kesiapan dalam memasuki pendidikan lebih lanjut. ${ }^{10}$

Sebagai permulaan dan pangkal pendidikan anak usia dini, maka pembiasaan merupakan harus diterapkan pada anak. Sejak dilahirkan anak harus dilatih dengan kebiasaan-kebiasaan dan perbuatan-perbuatan yang baik, seperti dimandikan, ditidurkan pada waktu tertentu, diberi makan dsb. Anak-anak dapat taat dan menurut kepada peraturan-peraturan dengan jalan membiasakannya dengan perbuatan yang baik, di dalam rumah tangga atau keluarga, sekolah, dan juga di tempat lain. ${ }^{11}$ Maka dari itu tepatlah kalau pembiasaan dijadikan sebagai metode dalam mendidik anak usia dini. anak bisa diarahkan dan dibimbing pada kebiasaan-kebiasaan dan perbuatan yang baik, karena anak berada pada usia sensitif, mudah dipengaruhi oleh lingkungan serta suka meniru.

\section{B. PEMBAHASAN}

\section{Pengenalan Nilai-Nilai Akhlak Mulia Melalui Metode Pembiasaan}

\section{a. Konsep Nilai}

Menurut Fraenkel yang dikutip oleh Moh. Roqib, nilai merupakan sebuah ide atau konsep mengenai sesuatu yang dianggap penting dalam kehidupan. Ketika seseorang menilai sesuatu, maka orang tersebut menganggap nilai itu penting, bermanfaat atau berharga untuk dipengenalankan. Selain itu, secara psikologis nilai merupakan serangkaian prinsip-prinsip

10 Undang-Undang RI No 20 Tahun 2003 tentang SISDIKNAS, (Bandung : Citra Umbara, 2005), hal. 4

${ }^{11}$ Armai Arief, Pengantar IImu Dan Metodologi Pendidikan Islam, (Jakarta: Ciputat Press, 2002), hal.110. 
yang menjadi petunjuk bagi tingkah laku seseorang. ${ }^{12}$ Nilai merupakan kualitas suatu hal yang menjadikan hal itu disukai, diinginkan, dikejar, dihargai, berguna dan dapat membuat orang yang menghayatinya menjadi bermartabat.Pengenalan nilai adalah proses menjadikan nilai sebagai bagian dari diri seseorang. ${ }^{13}$

\section{b. Akhlak Mulia}

Sementara kata "akhlak" juga berasal dari bahasa Arab, yaitu [خلق] jamaknya [أخلاق] yang artinya tingkah laku, perangai tabi'at, watak, moral atau budi pekerti. Dalam Kamus Besar Bahasa Indonesia, akhlak dapat diartikan budi pekerti, kelakuan. Jadi, akhlak merupakan sikap yang telah melekat pada diri seseorang dan secara spontan diwujudkan dalam tingkah laku atau perbuatan. Jika tindakan spontan itu baik menurut pandangan akal dan agama, maka disebut akhlak yang baik (mulia) atau akhlaqul karimah, atau akhlak mahmudah. Akan tetapi apabila tindakan spontan itu berupa perbuatan-perbuatan yang jelek, maka disebut akhlak tercela atau akhlakul madzmumah.

\section{c. Metode Pembiasaan}

Metode berasal dari kata "Method" yang berarti cara, menurutKamus IImiah Popular Internasional, "Method" atau metode berarti carayang disusun secara teratur, mapan, sistematis sebagai landasan untuksuatu kegiatan tertentu atau pelaksanaan sesuatu. ${ }^{14}$ Metode juga diartikansebagai cara yang telah teratur dan terfikir baik-baik untuk mencapai suatu maksud. ${ }^{15}$

\footnotetext{
12 Moh. Roqib, Prophetic Education Kontekstualisasi Filsafat dari Budaya Profetik dalam Pendidikan (Purwokerto: STAIN Press bekerjasama dengan Buku Litera, 2012), hal. 88.

13 Soedijarto, Menuju Pendidikan Nasional Yang Relevan Dan Bermutu (Jakarta: Balai Pustaka, 1993), Cet. 4, hal. 14.

${ }^{14}$ Budiono, Kamus Ilmiah Popular Internasional, (Surabaya: Alumni, 2005), hal. 404

${ }^{15}$ Tim Penyusun Kamus Pembinaan Dan Pengembangan Bahasa Indonesia, Kamus Besar Bahasa Indonesia Cet Ke-IV, (Jakarta: Balai Pustaka, 1999), hal.232.
} 
Sedangkan pembiasaan adalah melakukan sesuatu perbuatan atauketerampilan tertentu secara terus menerus dan konsisten untuk waktuyang cukup lama, sehingga perbuatan atau keterampilan itu benar-benardikuasai dan akhirnya menjadi suatu kebiasaan yang sulit untuk ditinggalkan. ${ }^{16}$ Dalam ilmu psikologi, proses pembiasaan disebut "Conditioning". Proses ini akan menjelmakan kebiasaan (habit) dan kemampuan (ability). Yang akhirnya akan menjadi sifat-sifat pribadi (personal habits) yang terperangai dalam perilaku sehari-hari. ${ }^{17}$ Dalam hal ini yang dimaksud adalah pembiasaan hal-hal yang baik, susila. Dalampenelitian ini yang dibidik adalah metode pembiasaan yang diberikan olehpendidik kepada peserta didik sehingga berpengaruh pada perilaku keseharian anak. Adapun kebiasaan positif dalam kehidupan tidak dapatdikuasai secara langsung oleh seseorang, walaupun berupa kebiasaan-kebiasaan yang dianggap sepele. Maka dengan alasan tersebut, lembagapendidikan anak usia dini (PAUD) sejak dini sudah menerapkan metode pembiasaan positif pada peserta didiknya yang disesuaikan dengan daya jangkau bagi anak usia dini. ${ }^{18}$

Pengenalan yang berimbas pada kebiasaan adalah faktor yang penting untuk terbiasa berakhlak karimah atau berperilaku baik. Anak seharusnya dilatih mulai dari tindakan yang kecil dan sederhana menuju tindakan yang lebih besar melalui kebiasaan yang dilatihkan. Ada sejumlah alasan untuk mengetahui bagaimana cara terbaik untuk membimbing tindakan/perilaku anak:

16 Hanna Djumhana, Integrasi Psikologi Dengan Islam Menuju Psikologi Islami, (Yogyakarta: Yayasan Insan Kamil dan Pustaka Pelajar, 2001), hal.126

${ }^{17}$ Hanna Djumhana, Integrasi Psikologi Dengan Islam Menuju Psikologi Islami, hal. 6

18 Suryati Sidharto dan Rita Eka Izzati, Pengembangan Kebiasaan Positif, (Yogyakarta:Pusat Penelitian Pendidikan Anak Usia Dini, 2007), hal. 1 
- Membantu anak belajar untuk membimbing dan bertanggung jawab terhadap perilaku mereka sendiri sama pentingnya dengan membantu mereka belajar membaca dan menulis.

- Membantu anak untuk bertindak secara bertanggung jawab dan membimbing perilaku mereka memberikan dasar bagi kehidupan yang produktif dan bertanggung jawab seumur hidup

- Ajaran, bimbingan dan keterampilan yang mereka pelajari akan bertahan seumur hidup

- Akar dari perilaku nakal dan menyimpang ada dalam usia dini. Perilaku-perilaku apa yang mengakibatkan masalah-masalah perilaku dimasa yang akan dating. Sebagai contoh, beberapa ciri khas anak pra sekolah yang menandai awal permasalahan perilaku remaja dan kenakalan meliputi perilaku merusa; tindakan yang berlebihan, sifat-sifat marah, gagal memenuhi sesuatu, penyerangan terhadap teman sebaya, dan dorongan hati yang kurang beraturan.

- Masyarakat semakin perihatin terhadap pengikisan kesopanan, dan perilaku buruk yang dirasakan sebagai kerusakan menyeluruh dari dari tanggung jawab pribadi. Satu alas an masyarakat mendanai system pendidikan pemerintah pada semua level adalah untuk membantu menjaga masyarakat tetap kuat dan sehat. Orang tua dan masyarakat mengharapkan pertolongan ahli anak usia dini untuk membantu anak belajar hidup bekerja sama dan sopan dalam masyrakat demokratis. Bergaul akrab dengan orang lain dan membimbing perilaku 
seseorang merupakan orestasi yang secara kultural dan sosial sangat berarti ${ }^{19}$.

Untuk mengembangkan kepribadian anak khususnya pada anak usia dini dimana mereka secara fitrah mempunyai aspek positif perkembangan moral, yang lebih dikenal saat ini sebagai perilaku prososial. Wilayah ini mencakup perilaku seperti empati, di mana anak-anak mengekspresikan kasih sayang dengan menghibur atau menyenangkan sesorang dalam kesusahan atau dengan mengungkapkan perasaan anak lainnya selama konflik interpersonal; kemurahan hati, di mana anak-anak berbagi atau memberikan miliknya pada seseorang, kerja sama, di mana anakanak bergiliran secara suka rela atau memenuhi permintaan dengan riang, dan kepedulian, dimana anak-anak membantu seseorang menyelesaikan tugas atau membantu seseorang yang membutuhkan. ${ }^{20}$

\section{Pengenalan Nilai-Nilai Akhlak Mulia Melalui Metode Pembiasaan Di RA Al Rosyid Bojonegoro.}

\section{Sekilas Tentang RA Al Rosyid}

RA Al-Rosyid didirikan pada tahun1988, awal mulai didirikan RA AlRosyid dikarenakan di sekitar lingkungan Ngumpakdalem belum ada pendidikan pra sekolah. Anak-anak usia dini langsung ke jenjang MI. Ada TK tapi lokasinya jauh, sehingga warga dan para tokoh agama tergerak hatinya untuk mendirikan RA Al-Rosyid sebagai embrio masuk ke MI. RA Al-Rosyid beralamat di Desa Ngumpakdalem Kecamatan Dander Kabupaten Bojonegoro Propinsi Jawa Timur, lembaga ini dibawah naungan Yayasan

${ }^{19}$ George S Morrison Dasar-Dasar Pendidikan Anak Usia Dini (PAUD), PT INdeks, Jakarta 2012, hal. 344.

20 Janice J Beaty, Observasi Perkembangan Anak Usia Dini, Kencana Prenadamedia Group, Jakatrta 2013, hal. 169 
Pendidikan Pondok Pesantren Al-Rosyid, berdasarkan surat keputusan/SK : W.m.06.02/2913/ket./1992 oleh Kepala Kantor Wilayah Departemen Agama Jawa Timur. Pada tahun 2008-2013 RA Al-Rosyid Ngumpakdalem terakreditasi A. Waktu penyelenggaraan proses pembelajaran dilakukan pada waktu pagi pukul 07.00 sampai pukul 10.00 .

Berdasarkan data dokumentasi yang peneliti peroleh dari tata usaha sekolah yang penulis anggap dapat membantu memberikan informasi tentang objek-objek penelitian, maka untuk lebih rinci berikut penulis cantumkan profil RA Al-Rosyid Ngumpakdalem.

\section{Visi Sekolah dan Misi Sekolah}

a. Visi RA Al-Rosyid

Terwujudnya generasi yang Islami, tangguh, berprestasi dan berbudi

b. Misi RA Al-Rosyid

1. Meningkatkan pendidikan agama Islam

2. Meningkatkan kerja sama dengan orang tua dalam menjagi kefitrahan anak

3. Meningkatkan pendidikan budi pekerti

4. Meningkatkan pendidikan olah raga dan kesehatan

5. Meningkatkan wawasan ilmu pengetahuan umum

6. Meningkatkan seni, bakat dan kreativitas

7. Meningkatkan motivasi anak dalam prestasi akademik dan non akademik

8. Mengupayakan anak didik untuk berjiwa Islami unggul dalam intelektual, emosional, spiritual agar berguna bagi nusa, bangsa dan agama.

\section{Tujuan Umum}

Tujuan Umum RA "AL-ROSYID" yaitu:

a. Membangun landasan bagi berkembangnya potensi peserta didik agar menjadi manusia beriman dan bertaqwa kepada Allah SWT, berakhlak mulia, sehat, berilmu, cakap, kreatif, inovatif, cerdas, 
mandiri, percaya diri dan menjadi warga negara yang demokratis, berbudi dan bertanggung jawab.

b. Mengembangkan potensi kecerdasan, intelektual, emosional, spiritual dan sosial peserta didik (IQ, EQ, SQ) pada masa emas pertumbuhannya dalam lingkungan bermain yang edukatif dan menyenangkan.

c. Membantu anak didik mengembangkan berbagai potensi baik psikis maupun fisik yang meliputi moral dan nilai-nilai agama, sosial emosional, kognitif, bahasa, fisik-motorik, kemandirian, dan seni untuk siap memasuki pendidikan dasar serta menghadapi masa depan.

\section{Tujuan Khusus}

Tujuan Khusus RA "AL-ROSYID" yaitu :

a. Anak mampu mengamalkan ajaran agama Islam

b. Anak santun dalam bergaul dengan siapapun serta percaya diri

c. Anak mampu membaca,menulis dan berhitung

d. Anak mampu membaca huruf - huruf Al Qur'an

e. Anak mampu berkreasi seni (menari, menyanyi, puisi, bermain peran, dll).

f. Anak mampu berprestasi dalam bidang akademik maupun non akademik.

\section{Pengenalan Nilai-Nilai Akhlak Mulia}

Nilai-nilai akhlak mulia yang dikenalkan pada anak usia dini di RA Al Rosyid Bojonegoro antara lain nilai pendidikan yang berasal dari nilainilai agama Islam yang bersumber dari al-Qur'an dan Hadits. Yakni nila religius, jujur, disiplin, tanggung jawab, mandiri, kreatif dan peduli sosial. Meskipun dalam praktiknya di RA yang siswa-siswinya masih di bawah 
umur nilai-nilai yang dikenalkan sebagian besar adalah pengenalan sehingga anak pada masa baligh dan dewasa akan mengenal lebih lanjut dengan disertai pengamalan yang baik dan penuh kesadaran.hal ini karena karena pada dasarnya setiap kegiatan yang ada di RA, baik kegiatan dalam pembiasaan, pembelajaran maupun pembiasaan diluar pembelajaran ini sarat dengan nilai-nilai akhlak mulia.

\section{Pendekatan yang digunakan dalam pengenalan nilai-nilai akhlak mulia}

Mengenalkan nilai-nilai akhlak .mulia kepada anak usia dini tidak akan berjalan dengan baik tanpa adanya sebuah pendekatan yang digunakan oleh guru, salah satu pendekatan yang bisa digunakan oleh guru yaitu;

1. Pendekatan pengenalan nilai melalui kegiatan pembiasaan yang dilakukan sehari-hari dilingkungan sekolah. Dalam hal ini guru dapat mengenalkan nilai-nilai akhlak mulia kepada anak usia dini dalam kegiatan pembiasaan sehari-hari di sekolah dalam pembelajaran, kegiatan ekstrakurikuler, dan dalam kegiatan yang tidak terprogram seperti kegiatan bermain yang dilakukan oleh anak-anak, dalam tata tertib, dan kegiatan lain yang sifatnya kondisional seperti persiapan lomba RA se-Kabupaten Bojonegoro dalam rangka HAB KEMENAG.

2. Metode keteladanan, Metode ini digunakan oleh guru untuk menyampaikan materi yang berkaitan dengan pendidikan akhlakul karimah dan pendidikan agama Islam, dan materi yang berkaitan dengan kemampuan dasar yang harus dicapai oleh anak usia dini meliputi bahasa, kognitif, dan fisik. Hal pertama yang harus dilakukan oleh guru sebelum melakukan pengenalan nilai-nilai akhlak mulia pada anak usia dini RA Al Rosyid Bojonegoro adalah dengan menciptakan figur teladan yang bisa diteladani oleh anak melalui seorang guru. Jadi sebelum melakukan pengenalan nilai-nilai akhlak 
mulia maka guru harus terlebih dahulu memiliki karakter yang baik sebelum mereka mengajar peserta didik.

\section{Langkah-Langkah Dalam Pengenalan Nilai-Nilai Akhlak Mulia}

Dengan cara melakukan kerjasama antara guru dengan orang tua anak dan dengan anggota masyarakat. Guru menghimbau kepada orang tua untuk mengajarkan kedisiplinan yang hendaknya diajarakan di rumah yaitu melalui shalat berjamaah, orang tua bisa mengajak anaknya untuk shalat bersama-sama, mengajak anak mereka untuk mengaji baik di TPQ, maupun di mushola, membiasakan bangun pagi dan shalat subuh bersama-sama, belajar setiap hari, dan kegiatan lainnya, sehingga peserta didik akan dengan mudah mengikuti peraturan yang ada di sekolah. Selain itu, guru juga membangun kerjasama dengan masyarakat sebagai lingkungan tempat anak usia dini belajar, hal ini dilakukan karena sebagian besar anak-anak menghabiskan waktu setelah sepulang dari sekolah adalah di lingkungan masyarakat. Bentuk kerjasama yang dilakukan oleh guru dengan masyarakat adalah dengan menyertakan anggota masyarakat dalam rapat, guru menghimbau kepada anggota masyarakat untuk menyediakan lingkungan yang religius dan kondusif untuk mengembangan nilai-nilai akhlak mulia peduli sosial dan komunikatif dengan menyediakan sarana belajar yang bisa diikuti oleh peserta didik seperti TPQ/TPA.

\section{Kegiatan Yang Termasuk Kedalam Pembiasaan Yang Dilakukan Sebelum} Kegiatan Pembelajaran Dimulai

Sebelum kegiatan belajar mengajar dilaksanankan, guru melakukan beberapa kegiatan pembiasaan yang dilakukan sehari-hari 
disekolah meliputi kegiatan pembiasaan membaca iqra yang dilakukan setiap hari senin sampai dengan hari rabu, pembiasaan membaca, manghafal rangkaian abjad maupun angka dalam bahasa Indonesia, bahasa Jawa, bahasa Inggris maupun bahasa Arab pada hari kamis, dan pembiasaan hafalan surat-surat pendek yang dilakukan pada setiap hari jumat. Kegiatan pembiasaan dilakukan sebelum pembelajaran dimulai tepatnya pada pukul. 07.15 sampai dengan pukul 08.00 WIB atau kondisional.

\section{Pelaksanaan Pengenalan Nilai-Nilai Akhlak Mulia}

Sebelum melakukan pengenalan nilai-nilai akhlak mulia pada anak usia dii RA Al Rosyid Bojonegoro, terlebih dahulu guru melakukan tahap yang pertama yakni tahap persiapan, yang mana nanti guru akan mengorganisir nilai-nilai apasaja yang hendak dikenalkan kepada anak, selanjutnya tahap mengetahui nilai, memahami nilai, menerima nilai dan tahap mengamalkan nilai, dimana pada tiap tahapan itu guru tetap memberikan arahan serta bimbingan kepada anak-anak, mengigat mera masih dalam fase anak usia dini.

\section{Penilaian Dalam Pengenalan Nilai-Nilai Akhlak Mulia Pada Anak}

Dalam melakukan penilaian perkembangan pemikiran anak usia dini bisa menggunakan penilaian portofolio, observasi, catatan anekdot, percakapan, penugasan, unjuk kerja dan hasil karya. Penilaian portofolio dilakukan berdasarkan hasil kerja anak dan catatatan/ dokumen tentang kemampuan anak dalam bahasa, sosial, emosi, moral dan nilai keagamaan serta kemandirian selama proses pembelajaran berlangsung. Hasil karya yang dihasilkan oleh anak dan dokumendokumen perkembangan anak yang telah dimiliki guru itu terlebih dahulu dianalisis untuk mengatahui tingkat perkembangan yang telah dicapai oleh mereka, 
setelah hasil karya dan dokumen itu dikumpulkan dalam satu bendel untuk masing-masing anak, barulah guru menarik kesimpulan tentang gambaran akhir perkembangan anak usia dini berdasarkan semua indikator yang telah ditetapkan persemster.

\section{KESIMPULAN}

Dari uraian dan pembahasan tentang "Pengenalan Nilai-Nilai Akhlak Mulia Melalui Metode Pembiasaan di RA Al Rosyid Bojonegoro" maka peneliti dapat menarik kesimpulan sebagai berikut:

1. Nilai-Nilai Akhlak mulia Pada Anak Usia Dini di RA Al Rosyid Bojonegoro yang diterapkan pada anak dengan metode pembiasaan berjalan efektif, Karen pada usia tersebut, anak dapat diatur dan diarahkan serta dibimbing untuk melakukan hal-hal positif. Maka dengan pembiasaan dan pengarahan tersebut akan menjadi kebiasaan baginya dalam kehidupan sehari-hari,karena anak juga sudah bisa memahami aturan, dan tentang baik buruk suatu perilaku.

2. Metode pembiasaan dalam Pengenalan Akhlak mulia bagi anak usia dini di RA Al Rosyid dilakukan secara kontinyu atau terus menerus dengan pengawasan dan dampingan dari para pendidik sehingga berjalan efektif dan efisien, serta diharapkan dapat menjadi kebiasaan positif yang selalu melekat dalam diri. Anak diajarkan sambil melakukan apa yang dipelajari sehingga anak bisa faham dan langsungmempraktikkan, dengan harapan kebiasaan yang dilakukan sejak kecil d sekolah dapat dijadikan kebiasaan pula ketika berada di lingkungan asyarakat dan dijadikan kebiasaan baik sepanjang hidupnya. 


\section{DAFTAR PUSTAKA}

Arief, Armai, (2002), Pengantar IImu Dan Metodologi Pendidikan Islam, Jakarta: Ciputat Press,

Asmani, Ma'mur, Jamal, (2009), Manajemen Stategis Pendidikan Anak Usia Dini, Yogyakarta: Diva Press,

Beaty, J Janice, (2013), Observasi Perkembangan Anak Usia Dini, Kencana Prenadamedia Group, Jakatrta

Budiono, (2005), Kamus IImiah Popular Internasional, Surabaya: Alumni,

Departemen Pendidikan dan Kebudayaan, (2007), Kamus Besar Bahasa Indonesia, Jakarta: Balai Pustaka,

Hanna Djumhana, Hanna, (2001), Integrasi Psikologi Dengan Islam Menuju Psikologi Islami, Yogyakarta: Yayasan Insan Kamil dan Pustaka Pelajar,

Moh. Roqib, (2012), Prophetic Education Kontekstualisasi Filsafat dari Budaya Profetik dalam Pendidikan, Purwokerto: STAIN Press bekerjasama dengan Buku Litera,

Morrison S George, (2012), Dasar-Dasar Pendidikan Anak Usia Dini (PAUD), PT INdeks, Jakarta,

Mursid, (2010), Manajemen Lembaga Pendidikan Anak Usia Dini, Semarang: Akfi Media,

Mursid, (2010). Kurikulum Dan Pendidikan Anak Usia Dini (PAUD), Semarang : AKFI Media,

Muslich, Masnur, (2011), Pendidikan Karakter Menjawab Tantangan Krisis Multidimensional, Jakarta: Bumi Aksara,

Sidharto Suryati dan Izzati,Eka, Rita, (2007), Pengembangan Kebiasaan Positif, Yogyakarta:Pusat Penelitian Pendidikan Anak Usia Dini,

Soedijarto, (1993), Menuju Pendidikan Nasional Yang Relevan Dan Bermutu Jakarta: Balai Pustaka,

Suyanto, Slamet, (2005), Dasar-Dasar Pendidikan Anak Usia Dini, Yogyakarta: Hikayat Publishing, 
Tafsir, Ahmad, (2000) Pendidikan Agama Dalam Keluarga, Bandung : Remaja Rosdakarya,

Tim Penyusun Kamus Pembinaan Dan Pengembangan Bahasa Indonesia,(1999), Kamus Besar Bahasa Indonesia Cet Ke-IV, Jakarta: Balai Pustaka,

Undang-Undang RI No 20 Tahun 2003 tentang SISDIKNAS, (2005), Bandung : Citra Umbara, 